\title{
The availability of full match sibling donors and feasibility of allogeneic bone marrow transplantation in Brazil
}

\author{
K.A.B. Eid, E.C.M. Miranda, \\ A.C. Vigorito, F.J.P. Aranha, \\ G.B. Oliveira and \\ C.A. De Souza
}

Unidade de Transplante de Medula, Universidade Estadual de Campinas, Campinas, SP, Brasil

\section{Correspondence}

C.A. De Souza

Centro de Hematologia e

Hemoterapia e Unidade de

Transplante de Medula Óssea

UNICAMP

Caixa Postal 6198

13081-970 Campinas, SP

Brasil

E-mail: carmino@unicamp.br

Publication supported by FAPESP. $\ldots \ldots \ldots \ldots \ldots \ldots \ldots$

Received October 24, 2001 Accepted November 18, 2002

\begin{abstract}
The feasibility of allogeneic bone marrow transplantation (alloBMT) in a developing country has not yet been demonstrated. Many adverse factors including social and economic limitations may reduce the overall results of this complex and expensive procedure. Our objective was to characterize the most important clinical, social and economic features of candidates for transplantation and their potential donors as well as the influence of these factors on overall survival in a retrospective and exploratory analysis at a university hospital. From July 1993 to July 2001, candidates for BMT were referred to the Bone Marrow Transplantation Unit by Hematology and Oncology Centers from several regions of Brazil. A total of 1138 patients were referred to us as candidates for alloBMT. Median age was 25 years (range: 2 months-60 years), 684 (60.1\%) were males and 454 (39.9\%) were females. The clinical indications were severe aplastic anemia and hematological malignancies. From the total of 1138 patients, 923 had HLA-typing; 497/923 (53.8\%) candidates had full match donors; 352/ $1138(30.8 \%)$ were eligible for alloBMT. Only 235 of $352(66.7 \%)$ were transplanted. Schooling was 1st to 8th grade for 123/235 (52.3\%); monthly family income ranged from US\$60 (7\%) to more than US $\$ 400$ $(36 \%)$. Overall survival for patients with chronic myeloid leukemia, severe aplastic anemia and acute myeloid leukemia was 58,60 and $30 \%$, respectively. Thus, overall survival rates for the most frequent hematological diseases were similar to those reported in the International Registry, except for acute myeloid leukemia. This descriptive and exploratory analysis suggests the feasibility of alloBMT in a developing country like Brazil.
\end{abstract}

\section{Introduction}

Brazil is a developing country with about 170 million inhabitants. Most of its population lives in the southeast and south, the richest region of the country (1). However, the median family income is only up to
Key words

- Allogeneic bone marrow

transplantation

- Selection of donors

- Social and economic

conditions 
additional risks in terms of treatment and socioeconomic support.

The first operating BMT unit in Brazil began its activity in Curitiba, Parana State, in 1980 (4). However, the procedure became available at many university hospitals mainly in the southeast only in the 1990's.

AlloBMT is a complex and expensive medical procedure. In the US the median cost of this therapy is about US $\$ 193,000$ per procedure (5). There are no data concerning the costs of this procedure in Brazil. AlloBMT is an important modality of treatment, in many cases the only possibility of cure or disease control. In many countries, bone marrow is the second most transplanted tissue (6). AlloBMT requires the cooperation and understanding of the patients and their families. Stress and anxiety from feelings of uncertainty about the future and fears about treatment must be evaluated (7). In addition, minimal life conditions to bear the several phases of transplant are important for the success of the procedure (7). All relevant information must be given to the patients and relatives in order to obtain maximum cooperation, independent of social or economic conditions.

The Bone Marrow Transplantation Unit of the State University of Campinas, São Paulo State, performed its first transplant in September 1993. At the beginning of the local program, coordinators had many doubts related to the feasibility of alloBMT in a country such as Brazil, mainly because most of the patients were poor and presented unfavorable living conditions. Moreover, our public hospital is free and responsible for medical assistance to about 6 million people without medical insurance living around metropolitan Campinas (8). In this study, our aim was to characterize the most important clinical, social and economic features of candidates for transplant and their potential donors. We also intend to analyze the patients treated with alloBMT at our institution, and the influence of the most important factors in terms of survival.

\section{Patients and Methods}

This is a retrospective and exploratory study in which we analyzed 1138 patients referred to our unit for alloBMT from July 1993 to July 2001. The candidates came from different Hematology and Oncology Centers in several states of Brazil. A preliminary form containing name, age, origin, diagnosis and number of possible sibling donors was completed for each patient. The first contact was made by fax, phone, letter, or e-mail or directly from physician to physician or through the Social Service of the Bone Marrow Transplantation Unit. After the first contact, candidates and donors were called to the unit and blood from both groups was sent to the histocompatibility laboratory in order to confirm or exclude donor compatibility for transplant. During this phase, HLA loci A and B (class I) from candidates and donors were determined. When this analysis demonstrated full compatibility between candidates and donors, class II and/or mixed lymphocyte culture was performed (9-12).

\section{Pre-bone marrow transplantation ambulatory visit}

The candidates with full match donors were scheduled for a pre-BMT ambulatory visit since they met the requirements of the institutional protocols. First of all, a detailed explanation about the procedure and its potential complications was given to patients and donors. At the same time all patients and donors were evaluated for psychological (13-19), transfusional (20), clinical and laboratory conditions.

Patient eligibility criteria were as follows: age $<60$ years, Eastern Cooperative Group (ECOG) performance status $<2$, creatinine clearance above $50 \mathrm{mg} / \mathrm{dl}$, left ventricular ejection fraction more than $45 \%$, pulmo- 
nary function (functional vital capacity) more than $60 \%$, negative serology for HIV and HLTV-I, negative active $\mathrm{B}$ or $\mathrm{C}$ hepatitis virus and absence of renal or hepatic function, no lack of a caregiver, and favorable socioeconomic conditions. Unfavorable socioeconomic conditions are defined by our institution as living without piped or filtered water or basic sanitation, and not having enough money to buy adequate food, medications, transportation, etc. Our institution provides special support to these patients, including nourishment, transportation and many times free lodgings near the hospital, not only for the patients but also for their caregivers, mainly during the first year after transplant.

Donors' eligibility criteria were good general health, negative serology for HIV and HLTV-I, negative active $\mathrm{B}$ or $\mathrm{C}$ hepatitis virus, and no Chagas' disease.

Peripheral blood progenitor cell donors were also evaluated in terms of availability of peripheral veins for apheresis when indicated. Red blood cell typing was performed and compatibility for $\mathrm{ABO}$ group, Rhesus factor and subsets was determined for both patients and donors. When all criteria were satisfied, informed consent was obtained from all patients and donors. The study protocols were approved by the local Ethics Committee.

\section{Statistical analysis}

Descriptive statistics based on univariate summaries for several variables at different times was used. This process was first applied to all candidates, then to all candidates eligible for transplant, and finally to the transplanted patients, with the actuarial curves added for this group according to the Kaplan-Meier method (21). Overall survival was analyzed according to years of schooling (up to 8 years, 8 to 12 years, more than 12 years), family income (up to US\$240, from US\$241 to US\$399, and above US\$400), and according to primary disease. These analyses were performed using the SPSS software, version 10.0 for Windows.

\section{Results}

We first analyzed 1138 candidates, 943 (83\%) from São Paulo State, 95 (8.3\%) from Minas Gerais State, and 100 (8.7\%) from other states. Of these, $684(60.1 \%)$ were males and 454 (39.9\%) were females. Median age was 25 years (range: 2 months- 60 years). The main clinical hypotheses were: 317 cases $(27.9 \%)$ of chronic myeloid leukemia, 258 cases $(22.7 \%)$ of acute myeloid leukemia (AML), 198 cases (17.4\%) of acute lymphoblastic leukemia, 144 cases (12.7\%) of severe aplastic anemia, 67 cases $(5.9 \%)$ of myelodysplastic syndrome, 83 cases $(7.3 \%)$ of malignant lymphomas, 30 cases $(2.6 \%)$ of multiple myeloma, and 41 cases $(3.5 \%)$ of other diseases. The median number of possible donors per patient (siblings) was 3 (range 0-15). After the selection procedure the median number of full match donors was 1 (range 1-5). For $102(9.0 \%)$ candidates the parents were studied in order to confirm the HLA typing. From the total of 1138 candidates, 923 had HLA-typing and 497/923 (53.8\%) had full match donors and were included in the clinical and laboratory screening for transplant; 641 (56.4\%) were considered ineligible to undergo a transplant at our unit. The characteristics of the referred and transplanted patients are summarized in Table 1. Table 2 shows the main causes of exclusion for transplant before medical evaluation.

Of the 497 (53.8\%) candidates who had a full match donor as determined by HLA typing, $145(29.3 \%)$ were not eligible for transplant, most of them $(75,51.7 \%)$ due to diseases excluded by the current protocols. The remaining 70 patients $(48.3 \%)$ did not present the clinical, psychiatric, or socioeconomic conditions required for transplantation. 
Table 1. Characteristics of patients referred and transplanted.

\begin{tabular}{lcc}
\hline & No. & $\%$ \\
\hline Candidates for transplant & 1138 & 100.0 \\
Gender & & \\
$\quad$ Male & 684 & 60.1 \\
Female & 454 & 39.9 \\
Refereed diseases & & \\
CML & 317 & 27.9 \\
AML & 258 & 22.7 \\
ALL & 198 & 17.4 \\
SAA & 144 & 12.7 \\
Malignant lymphomas & 83 & 7.3 \\
MDS & 67 & 5.9 \\
Multiple myeloma & 30 & 2.6 \\
Others & 41 & 3.5 \\
Median of brothers (range) & $3(0-15)$ & \\
No. of patients with full match donors & $497 / 923$ & $53.8 / 100$ \\
Median of full match donors (range) & $1(1-5)$ & \\
Transplanted patients/patients with donors & $235 / 497$ & $47.2 / 100$ \\
Gender & & \\
Male & 150 & 64 \\
Female & 85 & 36 \\
Transplanted diseases & & \\
CML & 100 & 42 \\
SAA & 46 & 20 \\
AML & 170 \\
ALL & 15 & 8 \\
MDS & 15 & 6 \\
Others & & 70 \\
\hline
\end{tabular}

$\mathrm{CML}$, chronic myeloid leukemia; $\mathrm{AML}$, acute myeloid leukemia; $\mathrm{ALL}$, acute lymphoblastic leukemia; SAA, severe aplastic anemia; MDS, myelodysplastic syndrome.

\begin{tabular}{lrr}
$\begin{array}{l}\text { Table 2. Causes of exclusion of candidates/patients for allogeneic bone } \\
\text { marrow transplantation. }\end{array}$ & No. & $\%$ \\
\hline Causes & 426 & 66.2 \\
\hline Incompatibility HLA & & \\
Lack of HLA typing due to: & 113 & 17.5 \\
No return & 46 & 7.1 \\
Patient's death & 19 & 3.0 \\
Diseases not included in protocols & 15 & 2.3 \\
No brothers & 9 & 1.4 \\
Donors not localized & 7 & 1.1 \\
Refused exams & 6 & 0.9 \\
Inconclusive results & 641 & 100.0 \\
Total of excluded patients & & \\
\hline
\end{tabular}

HLA, histocompatibility leukocyte antigen.
Of the $352(30.8 \%)$ candidates eligible for transplantation, however, only 235 of the total of 1138 candidates $(20.6 \%)$ were transplanted. Of the $117 / 352(33.2 \%)$ non-transplanted patients, 40 (11.4\%) had died before BMT, most of them due to hematological diseases, $21(6.0 \%)$ had unfavorable clinical or socioeconomic conditions at the time of transplant, 18 (5.1\%) were lost to follow-up, $16(4.5 \%)$ are still on line for a transplant, 9 (2.6\%) were abandoned by their donors, and $5(1.4 \%)$ were transplanted at other units.

The first transplant was performed at our unit in September 1993. Of 235 transplanted patients, $77 \%$ were from São Paulo State, $10 \%$ from Minas Gerais State and 13\% from other states. Sixty-four percent of the patients were males and 36\% females. Seventy-eight percent of patients were Caucasians, 19\% Afro-Brazilians and 3\% Japanese descendants. Median age was 29.2 years (range: 3.3-59.3). Educational level was elementary school for 123 of $235(52.3 \%)$ patients, incomplete in most cases. According to the International Bone Marrow Transplantation Registry (IBMTR) standard of scholarship, 4 patients $(1.7 \%)$ were illiterate, $142(60.4 \%)$ had completed 1 to 8 grades and $22(9.3 \%)$ had a college degree (BS/ BA). Overall survival according to schooling did not differ between groups (Figure 1). Monthly family income ranged from US\$60 (7\%) to more than US\$400 (36\%). Figure 2 shows better results for the groups with a family income below US $\$ 400$. In terms of professional activities, $87(37 \%)$ had a sales occupation, 57 (24\%) were students, $19(8 \%)$ were unemployed, and $72(31 \%)$ worked in other activities.

Figure 3 shows the overall 8-year survival for chronic myeloid leukemia, severe aplastic anemia and AML, which was 58, 60 and $30 \%$, respectively. The 8 -year survival of AML patients transplanted while in first complete remission $(\mathrm{N}=14)$ was $92 \%$, as opposed to $10 \%$ for patients with a first relapse or more advanced disease $(\mathrm{N}=26)$. 
The overall survival for other diseases is not presented due to the small number of cases.

\section{Discussion}

Data from IBMTR have shown a constant increase in the number of alloBMT worldwide (22). However, most of these transplants are being performed in North America, Western Europe, Japan, and Australia. The number of centers and transplants performed in South America, Africa, Western Europe, the Middle East, and East Asia is very low. The proportion between inhabitants and transplants performed in these regions is completely unbalanced, and many patients have no access to BMT units even when they have donors.

In Brazil, there was a delay in the development of BMT. The first unit performing BMT in Brazil was set up at the University Hospital of the Federal University of Paraná in the early eighties. In the nineties, many other centers began their activities. Data from the Brazilian Registry of Transplants suggest that only about $50 \%$ of patients with donors are transplanted today. Many factors are involved in this limit, but the most important is the unavailability of units and of enough beds. Most BMT centers are located in the south or southeast region of the country, the richest regions in Brazil. Brazil is a continental country, and travel and living expenses outside the home are a real limitation for many patients.

Among 170 million inhabitants, only 35 million have private medical insurance, while more than 135 million depend on governmental resources and structure, i.e., free medical care. Other important considerations are those linked to unfavorable living condition and the limited understanding ability of patients and their families. A high percentage of patients have low schooling and income. Nevertheless, our institution provides extensive social support including housing, transportation, drugs and medical assistance,

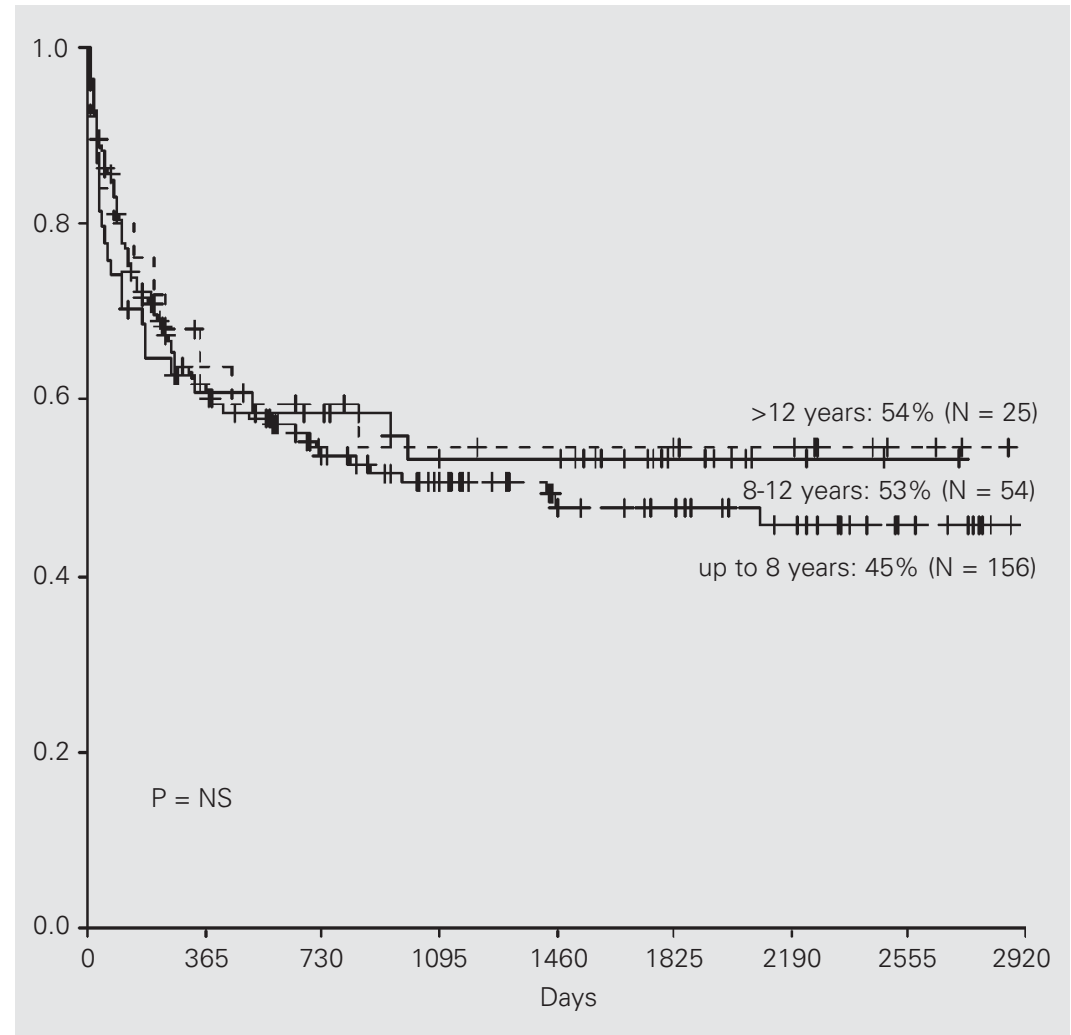

Figure 1. Overall survival according to years of schooling

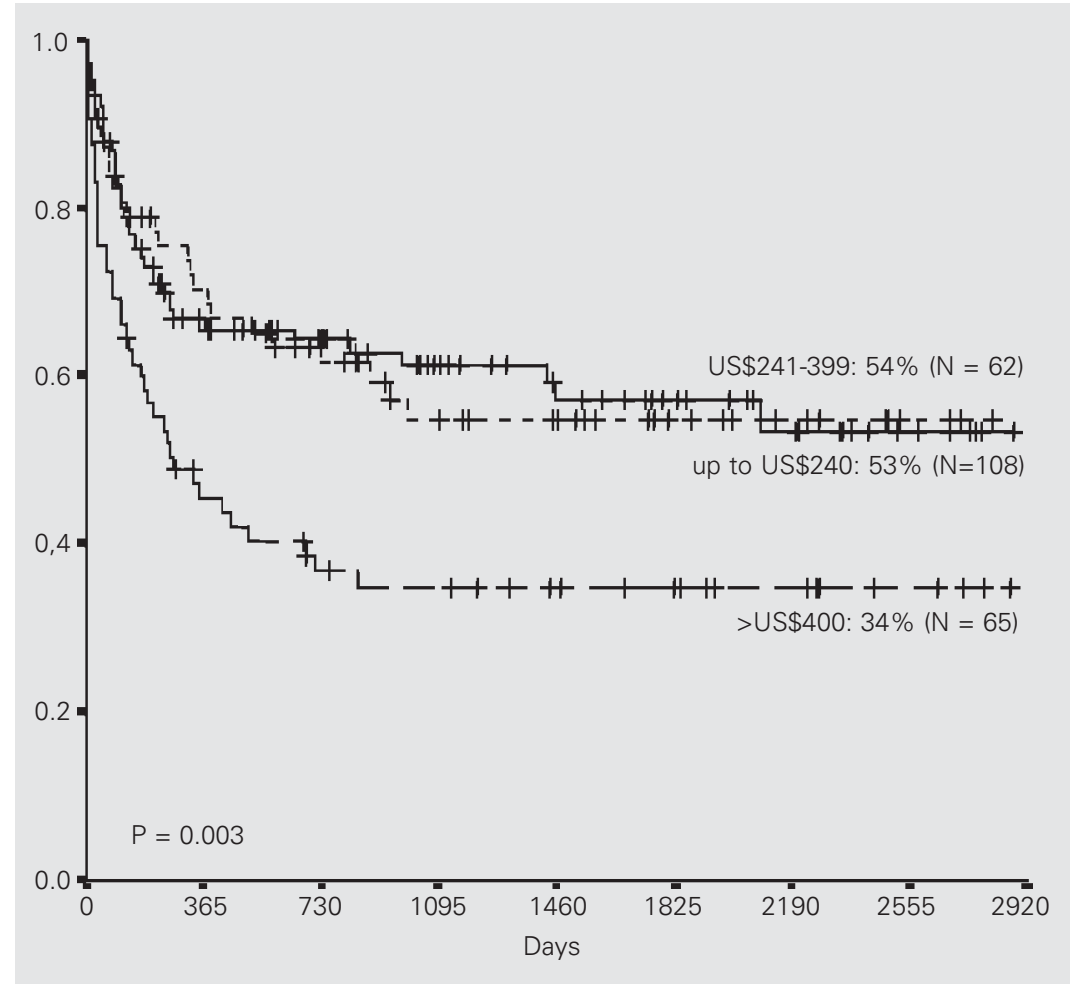

Figure 2. Overall survival according to family income. 


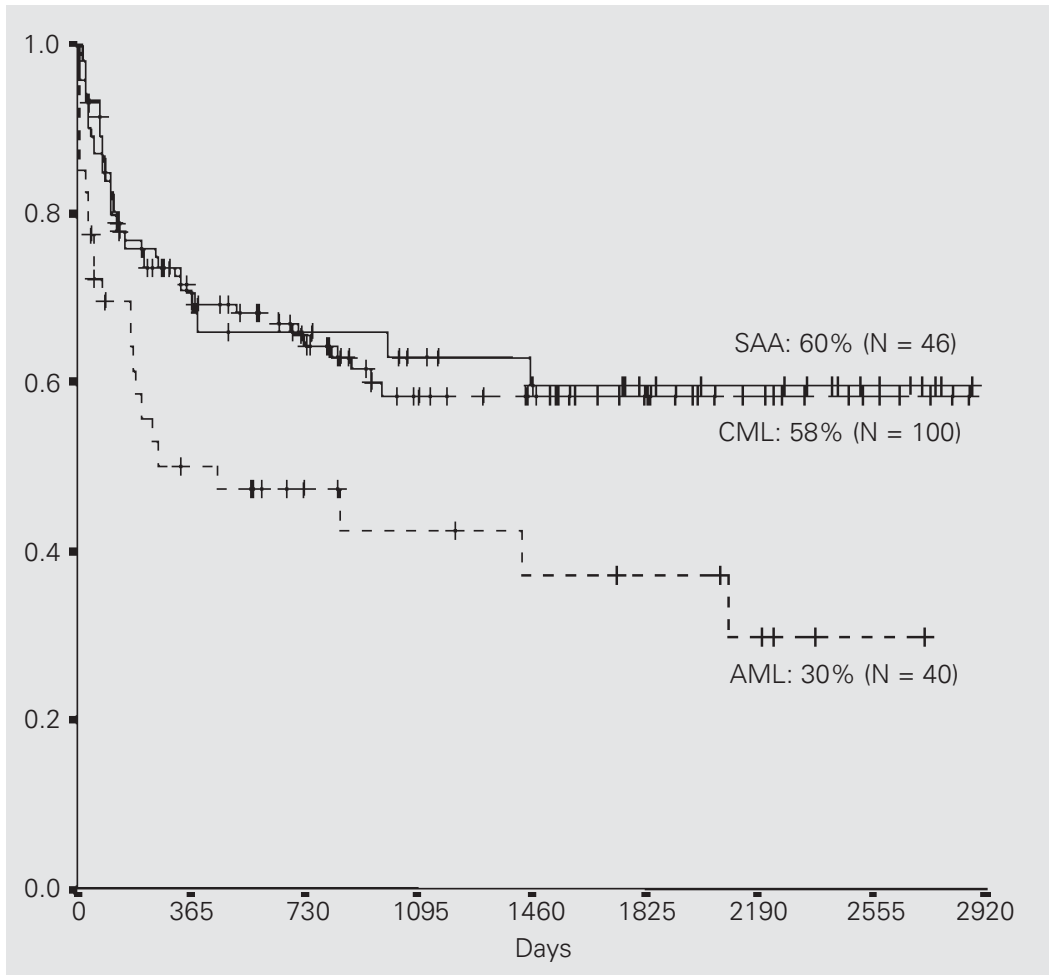

Figure 3. Overall survival of patients with chronic myeloid leukemia (CML), severe aplastic anemia (SAA), and acute myeloid leukemia (AML).

thus minimizing the influence of poverty factors. Although almost $54 \%$ of HLA-typed patients had full match donors, only $47 \%$ of them were transplanted. This undesirable fact probably has a complex explanation related to clinical, social, psychiatric or economic conditions, sometimes impossible to overcome, regardless of institutional structure.

Disconcerting also is the number of donors who abandoned their siblings or were not located (4.1\%) and the number of patients progressing and dying on the waiting line before transplant or still waiting for transplant (16\%). This is directly linked to the small number of beds available for transplant at our institution. An unexpected result was related to family income and survival. For reasons that we cannot explain, patients in the lower income group presented the best clinical results which were statistically significant $(\mathrm{P}=0.003)$. Perhaps patients in these groups had been submitted to a favorable social selection before arriving at the BMT unit.

Despite this unfavorable scenario, the overall results obtained in this analysis were similar to those reported by the International Registry, except for AML (22), whose results were lower than those reported in the literature. However, in terms of AML, our results using alloBMT were superior to those obtained using conventional chemotherapy alone and very good (92\%) for patients in first complete remission prior to alloBMT at our institution (23) and at other Brazilian institutions (24-27). This descriptive and exploratory analysis confirms the feasibility of alloBMT in a developing country like Brazil, despite difficulties for patients, families and the medical care system.

\section{Acknowledgments}

The authors thank Lucélia Bueno and Katia Regina de Jesus for important social assistance support, and Telma E.F. Oliveira for revising the English text.

\section{References}

1. Indicadores Sociais Mínimos (2000). Aspectos Demográficos. Fonte: IBGE/DPE/Departamento de Populações e Indicadores Sociais. Divisão de Estatutos e Análises da Dinâmica Demográfica. Projeto UNFPA/BRASIL (BRA/98/P08). Sistema Integrado de Projeções e Estimativas Populacionais e Indicadores Sócio Demográficos. Instituto Brasileiro de Geografia e Estatística, Rio de Janeiro, RJ, Brazil.

2. Indicadores Sociais Mínimos (2000). Trabalho e Rendimento. Fonte: Departamento de Contas Nacionais. Instituto Brasileiro de Geografia e Estatística, Rio de Janeiro, RJ, Brazil.

3. Indicadores Sociais Mínimos (2000). Educação e Condições de Vida. Fonte: Pesquisa Nacional por Amostra de Domicílios. Microdados.
Instituto Brasileiro de Geografia e Estatística. Rio de Janeiro, RJ, Brazil.

4. Ferreira E, Dulley FL, Morsoletto F, Neto JZ \& Pasquini R (1985). Bone marrow transplantation in Brazil. Human Immunology, 14: 324-332.

5. Westerman IL \& Bennett CL (1996). A review of the costs, costeffectiveness and third-party charges of bone marrow transplantation. Stem Cells, 3: 312-321.

6. Welch HG (1993). Marrow transplantation, cost effectiveness analysis and setting limits. Leukemia, 7: 1108-1111.

7. Whedon MB \& Fliedner MC (1999). Nursing issues in hematopoietic 
cell transplantation. In: Thomas ED, Blume KG \& Forman SJ (Editors), Hematopoietic Cell Transplantation. 2nd edn. Blackwell Scientific Publications, Malden, MA, USA, 381-385.

8. Secretária do Estado de Saúde (1994). Relatório Técnico de Gestão. Governo do Estado de São Paulo, São Paulo, SP, Brazil.

9. Harris R \& Ukaegrofo J (1970). Tissue typing using a routine one step lymphocyte separation procedure. British Journal of Haematology, 18: 229-231.

10. Charron D \& Fauchet R (1996). HLA DNA class II typing by PCRSSOP. In: Charon D (Editor), Technical Hand Book of the Twelfth International Histocompatibility Workshop. HLA et Médicine, Paris, France, 1: 21-25.

11. Bain BV, Vas L \& Lowenstein L (1968). A reaction between leukocytes in mixed peripheral blood cultures. Federation Proceedings, 22: $428-442$

12. Eiermann TH (1995). HLA and bone marrow transplantation. Archivum Immunologiae et Therapiae Experimentalis, 43: 83-87.

13. Blume KG \& Amylon MD (1999). The evaluation and counseling of candidates for hematopoietic cell transplantation. In: Thomas ED, Blume KG \& Forman SJ (Editors), Hematopoietic Cell Transplantation. 2nd edn. Blackwell Scientific Publications, Malden, MA, USA, 371-380.

14. Whedon MB \& Fliedner MC (1999). Nursing issues in hematopoietic cell transplantation. In: Thomas ED, Blume KG \& Forman SJ (Editors), Hematopoietic Cell Transplantation. 2nd edn. Blackwell Scientific Publications, Malden, MA, USA, 381-385.

15. Stewart SK (1999). The patient's perspective. In: Thomas ED, Blume KG \& Forman SJ (Editors), Hematopoietic Cell Transplantation. 2nd edn. Blackwell Scientific Publications, Malden, MA, USA, 386-389.

16. Streisand R, Rodrigue JR, Houck C, Graham-Pole J \& Berlant N (2000). Brief report: parents of children undergoing bone marrow transplantation: documenting stress and piloting a psychological intervention program. Journal of Pediatric Psychology, 25: 331-337.

17. Fabish $Y$, Leivzirher $H$ \& Lebel $M$ (2001). Role of bone marrow transplantation (BMT) nurse coordinator - a single center experience. Bone Marrow Transplantation, 27: 960 (Abstract).
18. Boer EA, Soeteman M, Pot M van der, Genee E \& Leiden NL (2001). Multi-cultural aspects and problems in BMT treatment for children. Bone Marrow Transplantation, 27: 912 (Abstract)

19. Chang G, Antil JH, Orav EJ, Randall U, McGarigle C \& Behr HM (1997). Substance abuse and bone marrow transplant. American Journal of Drug and Alcohol Abuse, 23: 301-308.

20. Slichter SJ (1988). Transfusion and bone marrow transplantation. Transfusion Medicine Reviews, 2: 1-17.

21. Kaplan EL \& Meier P (1958). Non parametric estimation from incomplete observation. Journal of the American Statistical Association, 53: 457-481.

22. Horowitz MM (2000). Report on state of the art in blood and marrow transplantation, IBMTR/ABMTR summary slides with guide. IBMTR/ ABMTR Newsletter, 7: 3-10.

23. Pagnano KBB, Traina F, Takahashi T, Oliveira GB, Rossini MS, Lorand-Metze I, Vigorito AC, Miranda ECM \& De Souza CA (2000). Conventional chemotherapy for acute myeloid leukemia: a Brazilian experience. São Paulo Medical Journal, 118: 173-178.

24. Pulcheri W, Spector N, Nucci M, Morais JCO, Pimenta G \& Oliveira HP (1995). The treatment of acute myeloid leukemia in Brazil: progress and obstacles. Haematologica, 80: 130-135

25. Bittencourt R, Capra MEZ, Cruz MS, Garcia RGG, Moreno F, João XXX \& Silla LMR (2001). Leucemia Mielóide Aguda: Experiência do Serviço de Hematologia do Hospital de Clínicas de Porto Alegre. Série de Monografias da Escola Brasileira de Hematologia, Rio de Janeiro, RJ, Brazil, 8: 91.

26. Fagundes EM, Rocha VG, Azevedo WM, Clementino NCD, Quintão JS, Ferraz MHC \& Viana MB (1995). Leucemia mielóide aguda no adulto: análise retrospectiva de 99 casos. Boletim - Revista da Sociedade Brasileira de Hematologia e Hemoterapia, 17: 33-39.

27. Llacer PED (1995). Tratamento quimioterápico da leucemia mielóide aguda: experiência de 16 anos da Disciplina de Hematologia e Hemoterapia da Faculdade de Medicina da Universidade de São Paulo. "Livre Docência" thesis, Faculdade de Medicina, USP, São Paulo, SP, Brazil. 